\title{
The Role of Sales Consultants in the Direct Marketing Strategy of Honda Kebon Jeruk West Jakarta in the Covid-19 Pandemic Era
}

\author{
Sugeng Dwi Nugroho', Denik Iswardani Witarti² \\ 1,2Universitas Budi Luhur Jakarta, Indonesia \\ Email: sugengdwi135@gmail.com
}

\begin{abstract}
Business actors have their way of finding and getting new customers. They develop the right marketing strategy to get new customers because they will win the business competition with their competitors. This study uses a qualitative research method with a case study approach the data used in primary data and secondary data. The methods used in data collection are interviews, observation and document review. Sampling using purposive sampling. The data analysis methods used are data reduction, data display, and conclusions drawing/verification methods. From the research results, it can be seen that: 1) Honda Kebon Jeruk has a breakthrough, namely collaborating with E-commerce such as Tokopedia in marketing their products; 2) Direct Marketing used in Honda Kebon Jeruk includes social media marketing, direct mail, telemarketing, digital marketing, and direct marketing; and 3) The role of sales consultants is significant in the success of the marketing strategy made by Honda Kebon Jeruk using the face to face customer method.
\end{abstract}

Keywords: Sales Consultant, Direct Marketing, Pandemic.

\section{A. INTRODUCTION}

In today's increasingly competitive business competition, even though the current economic conditions are not optimal due to the Covid-19 Pandemic, business people, especially in car sales services at Honda dealers, display their various competitive advantages in terms of service quality product quality, finance, technology and employees. Because many car dealers compete with each other to find and get consumers, various strategies and methods are applied to reach consumers and keep consumers loyal to them. Consumers not only need a car, but they also need full service when they want to buy a car and after making a purchase.

Business actors have their way of finding and getting new customers. They develop the right marketing strategy to get new customers because they will win the business competition with their competitors. They also carry out various marketing strategies in marketing their products. One of the strategies used is direct marketing. Direct marketing is essential because it targets carefully to get an immediate response and cultivate lasting customer relationships (Ambrose, Matthews \& Rutherford, 2018). The way to apply this strategy is by using a sales consultant (Ancillai, Terho, Cardinali \& Pascucci, 2019). The direct marketing strategies they are currently doing are canvassing, showroom events, catalogue marketing, face to face selling, telemarketing, television marketing, online marketing and direct mail (Bala \& Verma, 2018). 
The role of sales consultants in this pandemic period is significant in achieving sales targets during the PSBB period as currently, sales consultants must use other strategies in marketing their products, such as digital marketing, telemarketing. During the Covid-19 Pandemic, consumers have almost forgotten or may not know the latest type, then marketing through digital advertising will remind consumers and increase brand awareness again. This digital behaviour also encourages the expansion of online consumers not to the millennial generation but also to all ages (Costantini, Ceschi, Viragos \& Sartori, 2019).

In the sales process at Honda Kebon Jeruk, the sales consultant plays a role in selling various products from Honda cars, offering and providing clear information on Honda car products, ensuring the achievement of sales targets that the company has set, finding and preparing new customer prospects, reporting company sales activities/prospects customers to superiors, retaining existing customers, establishing good communication with customers. In the direct marketing strategy carried out by Honda Kebon Jeruk, the sales consultant role was added, starting from prospecting, qualifying, presentation, negotiation, closing, delivery, and follow-up to support sales at Honda Kebon Jeruk.

On the other hand, the Covid-19 pandemic that has hit the world, including Indonesia since the beginning of 2020, has had a negative impact on various sectors, including the car sales industry, which has been forced to work hard in achieving its sales due to the ongoing Covid 19 pandemic. Marketing, management, and business theories taught in the previous era almost no longer apply during the pandemic. So all business sectors also experience a new normal phase, where everything that is done by business people and consumers is all new (Kabadayi, O'Conor \& Tuzovic, 2020). This is none other than the way business people respond to the new normal period and the addition of the PSBB period during the pandemic. This makes the company must be able to behave and act appropriately in the face of competition (Leisen, Steffen \& Weber, 2019).

Direct marketing is one of the main activities in a marketing strategy (Chase \& Kumar, 2010). Its use is to persuade consumers, influence consumers, and provide complete information to consumers to use their products and make consumers loyal to their consumer's products (Chase \& Kumar, 2010). Direct marketing is very much talked about in recent years. Many companies use a marketing technique called direct marketing (Crabowski \& Stawasz, 2017). Manufacturers, service companies, retail traders, and non-profit organizations all compete in marketing their products or services using direct marketing (Tuzovic \& Kabadayi, 2020). Direct marketing allows a seller to more efficiently focus his attention on the mini market towards a more suitable offer by exploring the specific needs of consumers.

\section{B. METHOD}

This study employs a qualitative research method with a case study methodology, with primary and secondary data being employed. Interviews, observation, and document examination were utilized to obtain data. Sampling with 
the aid of purposive sampling. The data analysis techniques employed are data reduction, data display, and conclusion.

\section{RESULT AND DISCUSSION}

This communication activity is related to marketing, all forms of marketing or promotional activities will achieve their goals if they can be communicated appropriately and well. This is a challenge for communication actors in an agency when they are going to publish or socialize something to the public. The success or failure of a publication depends on the policies and marketing communication strategies. The importance of marketing is adjusted to the flow of globalization and the sophistication of information in all fields that are developing at this time and in the future.

Marketing communication is a type of communication that focuses on enhancing marketing methods in order to reach a broader market group. Businesses utilize a variety of marketing communications techniques to promote their products and services and to meet financial objectives. Advertising, sales force, retail signage, point-of-purchase displays, product packaging, direct mail, free product samples, coupons, publicity, and other communication tools all fall under the category of marketing activities that involve communication. In aggregate, the aforementioned actions comprise the promotional components of the marketing mix.

As explained above, that marketing communication is a company means to persuade consumers to the goods or services of a company, then this marketing communication is very important for a company to know and use it. This marketing communication must also be made as good as possible, as attractive as possible, so that potential consumers can pay attention and be interested in a company through marketing communications packaged through an advertisement. Not only interesting, marketing communications made by a company must follow the development of the era or trends and trends in consumer behavior at that time, companies must be very observant and sensitive to changes in consumer behavior which are also followed by other changes, such as those that are very clear that accompany changes Consumer behavior is a change in the development of technology. The development of technology is one of the biggest impacts for changes in consumer behavior, especially in terms of finding information, buying or using an item or service, and also communicating or socializing with others.

In this modern or digital era, people are getting smarter and more independent, along with technological developments. Because of technology, people can exchange information quickly and easily, and effectively. The result is that almost all human activities are connected through the internet network, it can be seen from the way they communicate, exchange information, find information, to make buying and selling transactions, even transportation that is connected to the internet network to order it. This new trend leads to the increasing complexity of consumers spending their time with smartphones that they have and which must be connected to the internet network, as a result they will give their full time to fulfill 
their information needs through the internet. This is where the birth of various kinds of websites and social media that were created to meet the needs of various consumer backgrounds began.

And through this, many companies began to focus on making advertisements that they spread through the internet, this was done because they realized that now consumers have started to switch and spend their time with smartphones that are connected to the internet network. And the trend of switching to the digital era can also be seen from the number of companies that now have brochures or price lists to invitations sent to consumers via the internet, it can also be seen at this time when we are looking for information on an item for example, such as a car for example, we You can get complete information, starting from price information, engine specifications, the shape of the car we are looking for which can also change color according to what is available, all through a website that is accessed via the internet.

In the current situation of the Covid-19 Pandemic, Honda Kebon Jeruk is faced with the problem of car sales which have decreased drastically. For more details, the following table will present data on sales of Honda car products in Kebon Jeruk through the following table:

Table 1 Car Sales Data at Honda Kebon Jeruk

\begin{tabular}{|c|c|c|c|}
\hline No & Month & The year 2019 (Units) & The year 2020 (Units) \\
\hline 1 & January & 111 & 14 \\
\hline 2 & February & 70 & 57 \\
\hline 3 & March & 102 & 25 \\
\hline 4 & April & 62 & 3 \\
\hline 5 & May & 72 & 13 \\
\hline 6 & June & 59 & 17 \\
\hline 7 & July & 86 & 21 \\
\hline 8 & August & 91 & 27 \\
\hline 9 & September & 66 & 27 \\
\hline 10 & October & 68 & $\mathbf{6 0}$ \\
\hline 11 & November & 101 & $\mathbf{3 0 8}$ \\
\hline 12 & December & 107 & $\mathbf{9 9 5}$ \\
\hline \multicolumn{3}{|c|}{ Amount } & Depreciated by $\mathbf{6 8 7}$ Units between 2019-2020 \\
\hline
\end{tabular}

Source: Honda Kebon Jeruk's Data

Based on the table, it can be seen that in the same month from March to December in different years between 2019 and 2020, there was a very drastic decrease, which was 571 units, wherein March 2020 was the start of the Covid-19 Pandemic from these conditions Honda Kebon Jeruk, must be able to maintain the loyalty of existing consumers and try to find new consumers in the era of the Covid19 Pandemic, especially sales consultants who have an essential role as the spearhead of the company, must continue to consistently pursue sales by following the Covid 19 health protocol as it is today. 


\section{The Role of Sales Consultants in Increasing Sales at Honda Kebon Jeruk}

Whatever the form of activities or programs carried out by a company or organization will get less effective results if one of the roles in the organization does not run optimally or is eliminated (Denzin \& Lincoln, 2012). Likewise, in marketing programs or car sales, relying on all teams, such as the marketing department, is insufficient to boost car sales figures at Honda Kebon Jeruk. Making a strategy before carrying out marketing activities will significantly help a company or institution achieve the set success targets (Cummings, 2010). To make the direct marketing strategy a success, Honda Kebon Jeruk has to prepare a lot. One of them is the role of sales consultant.

The way and role of sales in increasing sales at Honda Kebon Jeruk are to be diligent in following up with customers and holding meetings with customers. Knowledge of the products being sold and the sales consultant's communication style when doing follow-up will determine success in sales (Meithiana, Intan \& Suksesi, 2019). With knowledge and communication style and a good approach in doing follow-up will eventually get a positive response from the customer (Nissen, 2018).

By using the communication made by the sales consultant to the customer before buying and after-sales, it makes the customer feel satisfied with the services provided in addition to increasing sales of Honda Kebon Jeruk doing other ways such as additional services with several objectives such as getting extra income for Honda Kebon Jeruk from service and body repair other than that different goals are for consumer satisfaction to make consumers loyal to Honda Kebon Jeruk and hope that consumers will refer Honda Kebon Jeruk to their colleagues.

\section{Promotions by Honda Kebon Jeruk}

When determining the promotion, Honda Kebon Jeruk will make several options after the results are obtained. It will be evaluated whether this promotion will be continued or replaced with another advertising. Promotion requires media to disseminate information. The media used by Honda Kebon Jeruk in conducting promotions are Facebook, Instagram and Tokopedia. During a pandemic like this, the media used by Honda Kebon Jeruk helps do more upgrades, namely using online media in marketing their products, but at the final stage, they still use hardselling (Odekerken, Mele, Russo, Mahr \& Ruggiero, 2020). In this case, they meet face-to-face. Advertising media is beneficial in finding new consumers, although, in the end, it returns to the sales consultant's skills in managing the consumers themselves (Scherpen, Draghici \& Niemann, 2018). It can also be seen in the explanation above that Honda Kebon Jeruk has shifted its marketing strategy from hard selling to soft selling in its effort to get new customers.

\section{Honda Kebon Jeruk Direct Marketing Strategy}

Direct marketing is the final component of the communication and promotion mix, and it is divided into six categories, as follows: 1) Through direct mail. Direct 
mail is a letter that promotes our business/products and services directly to a targeted group of customers. Direct mail comes in a variety of forms, including product catalogues, product postcards, and mailers. 2) Place an order by e-mail. Email marketing is a simple, cost-effective, and scalable method of communicating with customers. This may include electronic newsletters, promotional e-mails designed to create new leads or special deals for existing clients, or adverts that appear in other firm e-mails. 3) Marketing via social media. Social media can be a very successful marketing tool for businesses. It enables us to communicate directly with customers and provide pertinent information about products and services on a consistent basis; 4) Sales by direct contact. Direct selling is an efficient method of establishing a scalable and economical business; Telemarketing 5) Telemarketing is the practice of contacting prospective clients via telephone to offer them a product or service. This strategy is effective in attracting new customers and serves as a tracking mechanism for direct marketing campaigns; 6) Internet marketing. Direct marketing can also be accomplished through the use of online marketing or online media. 7) Leaflets for marketing. This is a form of direct marketing in which flyers are distributed or sent to general customers or consumers. and 8) Shopping for televisions at home. Marketing via television or online commerce is gaining popularity. Numerous television stations broadcast this type of commercial programming.

There are two marketing strategies for Honda Kebon Jeruk: face-to-face and digital media (social media, website, marketplace). In addition, Honda Kebon Jeruk also cooperates with marketplaces such as Tokopedia; this is undoubtedly very helpful in terms of costs and sales. Honda Kebon Jeruk does not need to bother marketing and finding consumers. During a pandemic like this, the government implements many regulations and policies, especially the Jakarta Regional Government, which makes changes in marketing strategies.

Honda Kebon Jeruk has done digital marketing, and it's just that the portion is different. When doing digital marketing, they have to think about maximising digital marketing, such as making ads that contain/weight, engaging on social media and their website; in that way, it is hoped that consumers will be interested and increase sales. When the marketing strategy has been carried out, the company must make a difference because, in general, almost every company uses the same marketing strategy (Saniuk, Grabowska \& Gajdzik, 2020).

Honda Kebon Jeruk has made a difference in its marketing strategy since the recruitment of sales where they take young salespeople who are familiar with the technology so they can quickly adapt to the digital marketing strategy carried out by Honda Kebon Jeruk, besides that Honda Kebon Jeruk has sales with skills who are good at maintaining their customers so that sales increase. In the marketing strategy, there is one strategy that is widely used by business actors, namely, the direct marketing strategy. Even so, Honda Kebon Jeruk also carried out a straightforward marketing strategy in the marketing process. 
The direct marketing strategy at Honda Kebon Jeruk runs effectively, and they use many ways such as social media marketing, direct mail, telemarketing, digital marketing, and direct marketing. Still, the role of the sales consultant cannot be ruled out because, without a sales consultant, the customers cannot get more information (Patiar \& Wang, 2020). There is a lot about the product you want to buy and with the sales consultant the customers can be convinced that the choice is the right one (Reichstein, Giroud, Yamin \& Andersson, 2021).

However, there are several obstacles faced by Honda Kebon Jeruk, both from internal and external to the company. Constraints from internal in the form of different capabilities of the sales consultant, such as some who are only good at talking but are unable to attract the customer's heart so they can't close (Samiee, Shimp \& Sharma, 2003). In addition, external constraints, salespeople find it difficult to meet with customers because of regulations issued by the government during this pandemic, besides the transfer of cost allocations made to customers from consumptive to investment causes purchasing power to decrease. Meanwhile, when using social media, most customers are just asking questions.

In the direct marketing strategy run by Honda Kebon Jeruk, they adapt to today's era, namely digitalization. They do many things such as placing advertisements on websites, using Instagram, Instagram Tv and Facebook. The use of media that is carried out aims to cover a broader range and make it more known to the community and media promotion. Through digital media, especially during a pandemic, prospective consumers are easier to get, especially from e-commerce. Previously, to reach potential customers, Honda Kebon Jeruk conducted canvasing and exhibitions. The role of Sales Consultants, in this case, is very influential; they always follow up on potential customers to make purchases. Even though it is now the digital age, it is still the final face-to-face process that is very influential in determining purchasing decisions made by potential consumers.

\section{CONCLUSION}

From the research results, it can be seen that: 1) Honda Kebon Jeruk has a breakthrough, namely collaborating with E-commerce such as Tokopedia. Marketing strategy programs like this are still rarely used by similar business actors; Tokopedia is one of the largest e-commerce in Indonesia with a considerable number of users by seeing that Honda Kebon Jeruk advertises there in the hope of getting new customers; 2) Direct Marketing used in Honda Kebon Jeruk includes social media marketing, direct mail, telemarketing, digital marketing, and direct marketing; and 3) The role of sales consultants is significant in the success of the marketing strategy made by Honda Kebon Jeruk even though currently Honda Kebon Jeruk is switching to digital marketing, in the end, it is the face to face concept that determines the success of sales because with face to face customers will feel more confident in the decisions they make. 


\section{REFERENCES}

1. Ambrose, S. C., Matthews, L. M., \& Rutherford, B. N. (2018). Cross-functional teams and social identity theory: A study of sales and operations planning (S\&OP). Journal of Business Research, 92, 270-278.

2. Ancillai, C., Terho, H., Cardinali, S., \& Pascucci, F. (2019). Advancing social media driven sales research: Establishing conceptual foundations for B-to-B social selling. Industrial Marketing Management, 82, 293-308.

3. Bala, M., \& Verma, D. (2018). A critical review of digital marketing. M. Bala, D. Verma (2018). A Critical Review of Digital Marketing. International Journal of Management, IT E Engineering, 8(10), 321-339.

4. Chase, R., \& Kumar, R. (2010). Operations management consulting. In Management Consulting Today and Tomorrow (pp. 169-190). Routledge.

5. Costantini, A., Ceschi, A., Viragos, A., De Paola, F., \& Sartori, R. (2019). The role of a new strength-based intervention on organisation-based self-esteem and work engagement: A three-wave intervention study. Journal of Workplace Learning.

6. Crabowski, W., \& Stawasz, E. (2017). The role of business consulting in creating knowledge and formulating a strategy of development in Polish microenterprises. Journal of East European Management Studies, 374-396.

7. Cummings, T. (2010). Intervention strategies in management consulting. In Management Consulting Today and Tomorrow (pp. 297-320). Routledge.

8. Degeling, M., \& Berendt, B. (2018). What is wrong about Robocops as consultants? A technology-centric critique of predictive policing. $A i \mathcal{E}$ Society, 33(3), 347-356.

9. Denzin, N.K., \& Lincoln, Y.S. (2012). Introduction: The discipline and practice of qualitative research. The Sage handbook of qualitative research. Thousand Oaks, CA: Sage.

10. Kabadayi, S., O'Connor, G. E., \& Tuzovic, S. (2020). The impact of coronavirus on service ecosystems as service mega-disruptions. Journal of Services Marketing.

11. Leisen, R., Steffen, B., \& Weber, C. (2019). Regulatory risk and the resilience of new sustainable business models in the energy sector. Journal of cleaner production, 219, 865-878.

12. Meithiana, I., Intan, N. H., \& Sukesi, S. (2019). Customer loyalty: effects of sales information system, marcomm, and brandambassadors. Jurnal Studi Komunikasi, 3(2), 182-198.

13. Nissen, V. (2018). Digital transformation of the consulting industry-introduction and overview. In Digital Transformation of the Consulting Industry (pp. 1-58). Springer, Cham.

14. Odekerken-Schröder, G., Mele, C., Russo-Spena, T., Mahr, D., \& Ruggiero, A. (2020). Mitigating loneliness with companion robots in the COVID-19 pandemic and beyond: an integrative framework and research agenda. Journal of Service Management. 
15. Patiar, A., \& Wang, Y. (2020). Managers' leadership, compensation and benefits, and departments' performance: Evidence from upscale hotels in Australia. Journal of Hospitality and Tourism Management, 42, 29-39.

16. Reichstein-Scholz, H., Giroud, A., Yamin, M., \& Andersson, U. (2021). Sales to centre stage! Determinants of the division in strategic sales decisions within the MNE. International Business Review, 101859.

17. Samiee, S., Shimp, T. A., \& Sharma, S. (2003). Brand origin recognition accuracy: its antecedents and consumers' cognitive limitations. Journal of International Business Studies, 36(4), 379-397.

18. Saniuk, S., Grabowska, S., \& Gajdzik, B. (2020). Social expectations and market changes in the context of developing the Industry 4.0 concept. Sustainability, 12(4), 1362.

19. Scherpen, F., Draghici, A., \& Niemann, J. (2018). Customer experience management to leverage customer loyalty in the automotive industry. ProcediaSocial and Behavioral Sciences, 238, 374-380.

20. Seifert, H., \& Nissen, V. (2018). Virtualization of consulting services: state of research on digital transformation in consulting and future research demand. In Digital Transformation of the Consulting Industry (pp. 61-73). Springer, Cham.

21. Tuzovic, S., \& Kabadayi, S. (2020). The influence of social distancing on employee well-being: A conceptual framework and research agenda. Journal of Service Management. 